\title{
Cardiac pre-load alteration with MRI-compatible lower body suction device
}

Gergely V Szantho ${ }^{1 *}$, Chris B Lawton ${ }^{1}$, Stephen Lyen ${ }^{1}$, Chiara Bucciarelli-Ducci ${ }^{2}$, Nathan E Manghat ${ }^{1}$, Mark S Turner', Michael P Frenneaux ${ }^{3}$, Mark Hamilton ${ }^{2}$

From 18th Annual SCMR Scientific Sessions

Nice, France. 4-7 February 2015

\section{Background}

Our group studies circulatory causes of exercise limitation in congenital heart patients with dilated right ventricle, but normal resting left ventricular ejection fraction. Cardiac MRI is the gold standard non-invasive tool for measuring heart chamber volume and blood vessel flow. We designed an MRI-compatible lower body negative pressure (LBNP) device (Image) in order to study the effect of pre-load reduction on the heart with MRI. This is a pilot study to establish our methodology.

\section{Methods}

We measured ventricular volumes from standard contiguous short axis stack of gated SSFP cines (slice thickness $8 \mathrm{~mm}$ ), and great vessel flows just above the sino-tubular junction from standard phase contrast flow imaging at

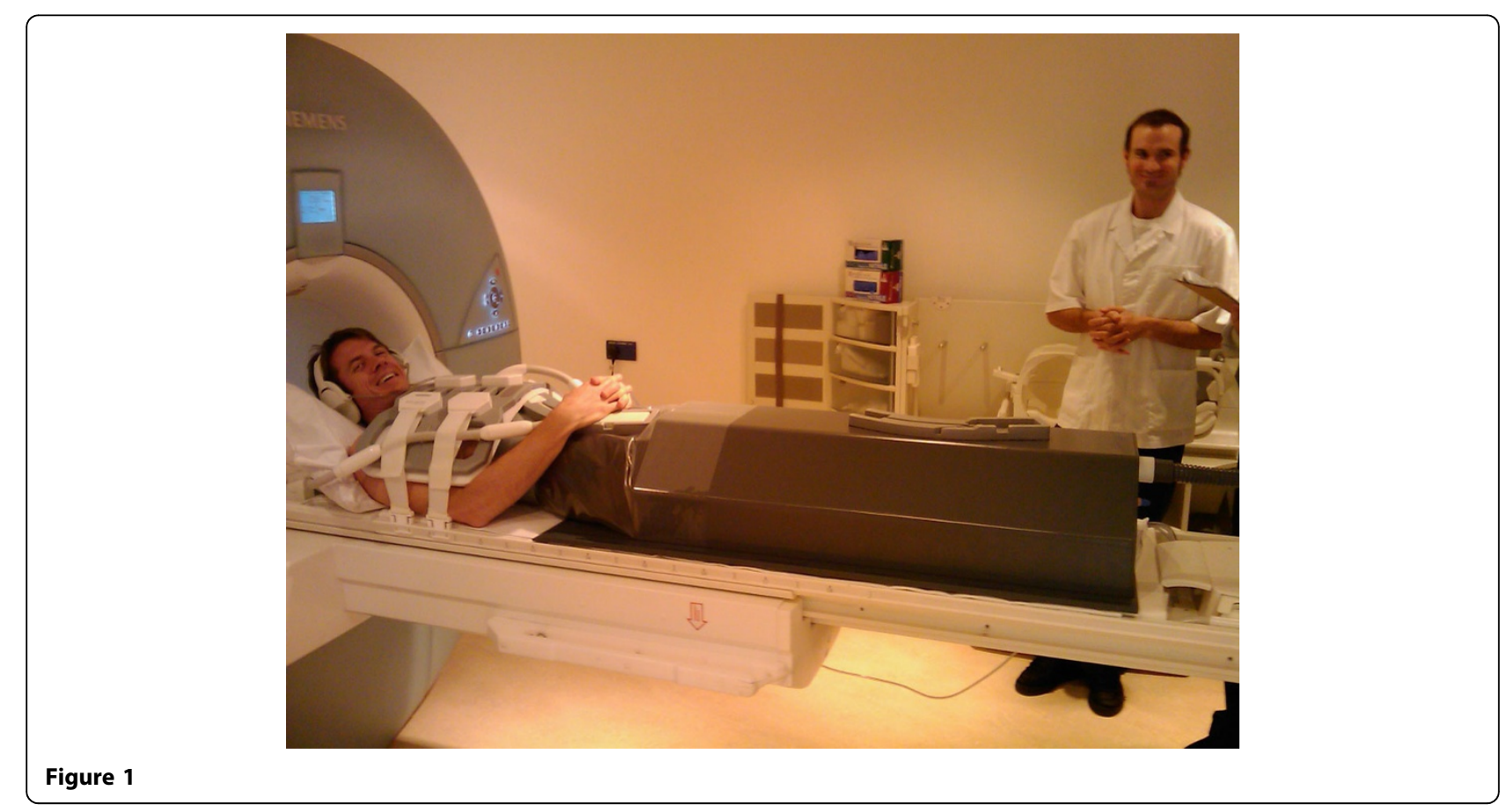

'Bristol Heart Institute, Bristol, UK

Full list of author information is available at the end of the article

(c) 2015 Szantho et al; licensee BioMed Central Ltd. This is an Open Access article distributed under the terms of the Creative Commons 
rest and at different levels of lower body vacuum $(-5$, -10 and $-20 \mathrm{mmHg}$ ) in nine healthy volunteers. We compared measurements taken at rest and different levels of vacuum with students' paired $\mathrm{t}$-test.

\section{Results}

We found that end-diastolic volume (EDV) and stroke volume (SV) progressively decreased with increasing lower body vacuum, in both ventricles. The difference between rest and $-20 \mathrm{mmHg}$ LBNP were as follows: LVEDV $160.64+-28.18 \mathrm{ml}$ vs $145.02+-25.61 \mathrm{ml}(\mathrm{p}<0.0005)$, LVSV $98.44+-15.88 \mathrm{ml}$ vs $84.9+-12.38 \mathrm{ml}(\mathrm{p}<0.005)$, RVEDV $174.81+-46.01 \mathrm{ml}$ vs $154.1+-34.65 \mathrm{ml}(\mathrm{p}<0.01)$, RVSV $100.11+-18.34 \mathrm{ml}$ vs $89.51+-17.62 \mathrm{ml}(\mathrm{p}<0.1 \mathrm{~ns})$.

Peak flow rate (PFR) and stroke volume measured with flow imaging also decreased both in the ascending aorta and the main pulmonary artery (MPA). The difference between rest and $-20 \mathrm{mmHg}$ LBNP were as follows: Aortic SV $88.11+-16.72 \mathrm{ml}$ vs $72.8+-13.85 \mathrm{ml}(\mathrm{p}<0.001)$, Aortic PFR $441.5+-75.84 \mathrm{ml} / \mathrm{s}$ vs $387.47+-56.01 \mathrm{ml} / \mathrm{s}(\mathrm{p}<0.002)$, MPA SV $105.25+-19.86 \mathrm{ml}$ vs $84.42+-20.7 \mathrm{ml}(\mathrm{p}<0.00002)$, MPA PFR $442.48+-84.38 \mathrm{ml} / \mathrm{s}$ vs $375.22+-6974 \mathrm{ml} / \mathrm{s}(\mathrm{p}<0.0002)$.

Heart rate (HR) increased slightly from rest at -20 mmHg LBNP: $63.58+-10.49 \mathrm{bpm}$ vs $69.43+-11.76 \mathrm{bpm}$ $(\mathrm{p}<0.01)$.

Interestingly RVEDV, RVSV and MPA SV were already significantly reduced at $-5 \mathrm{mmHg}$ LBNP $(165.9+-43.28 \mathrm{ml}$ $\mathrm{p}<0.002,89.34+-15.42 \mathrm{ml} \mathrm{p}<0.005,95.99+-15.75 \mathrm{p}<0.05$, respectively); and most of the other parameters changed significantly already at $-10 \mathrm{mmHg}$, which will be further disussed.

Blood pressure did not change significantly, and our volunteers did not indicate any discomfort.

\section{Conclusions}

Our pilot study shows that our MRI compatible LBNP device is safe, exerts adjustable and non-invasive pre-load reduction, and the physiological cardiac response to it is well detectable with cardiac MRI.

\section{Funding}

Funded by the general research budget of our Institution.

\section{Authors' details}

${ }^{1}$ Bristol Heart Institute, Bristol, UK. ${ }^{2}$ University of Bristol, Bristol, UK. ${ }^{3}$ University of Aberdeen, Aberdeen, UK.

Published: 3 February 2015

\section{doi:10.1186/1532-429X-17-S1-Q113}

Cite this article as: Szantho et al:: Cardiac pre-load alteration with MRIcompatible lower body suction device. Journal of Cardiovascular Magnetic Resonance 2015 17(Suppl 1):Q113.

\section{Submit your next manuscript to BioMed Central} and take full advantage of:

- Convenient online submission

- Thorough peer review

- No space constraints or color figure charges

- Immediate publication on acceptance

- Inclusion in PubMed, CAS, Scopus and Google Scholar

- Research which is freely available for redistribution 